\title{
Biological Evaluation of 2, 5-Di (4 Aryloylaryloxy Methyl) - 1, 3, 4-Oxadiazoles Derivatives as Antimicrobial Agents
}

Yasser Hussein Eissa Mohammed ${ }^{1,2}$, Gurupadaswamy HD $^{1}$ and Shaukath Ara Khanum ${ }^{\star *}$

${ }^{1}$ Department of Chemistry, Yuvaraja's College, University of Mysore, Mysore, Karnataka, India

${ }^{2}$ Department of Biochemistry, Applied Science College, University of Hajja, Yemen

\begin{abstract}
A series of potential biologically active substituted 2,5-di(4 aryloylaryloxymethyl)-1,3,4-oxadiazoles 9a-j were evaluated for its potential antimicrobial activity comparing with the standard drugs-Streptomycin and Ketoconazole respectively. Compound 9a with fluoro group exhibited highest activity against both gram-positive and gramnegative bacteria. Compounds $\mathbf{9 a}$ with fluoro group and $\mathbf{9 c}$ with fluoro and bromo showed good activity against antifungal activities.
\end{abstract}

Keywords: 1,3,4-Oxadiazoles; Synthesis; Antibacterial; Antimicrobial

\section{Introduction}

Infection of microbes is a serious problem in modern medicine. Among the most purchased drugs, antimicrobials drugs are usually used worldwide. Such a necessary treatment is needed especially in the upcoming world where infectious diseases are a common cause of death. An alarming level has been reached by the new emerging drug resistant micro-organisms around the world causing lifethreatening infectious diseases. Recently, the wound infections, blood stream infections are caused by the Staphylococcus aureus and that of Diarrhoea ("bacillary dysenteria") by the Shigella species [1]. An increasing number of immuno-compromised patients as a result of HIV infection, cancer chemotherapy and organ transplantation is also one of the major factors contributing to the increasing use of antimicrobial drugs. Also, the smart arising claim for the material protection from microbial infection has paved the way for the pharmacological research $[2,3]$. The above-mentioned fact is the cause for a great concern creating a insistent need for new anti-microbial agents. Despite of great effort from the pharmaceutical industry to manage the resistance problem, the discovery and development of new mechanistic classes of antibiotics has found very little success [4]. The difficulty of this task has been demonstrated by the fact that only two antibiotics of new classes, linezolid (an oxazolidinone) and daptomycin (a cyclic lipopeptide), have been successfully developed in the past three decades $[5,6]$. In the past 20 years, the incidence of microbial infection has reached a peak level over the world as a result of resistance against the drugs. The health problems pose to explore and synthesize a novel class of antimicrobial species effective against pathogenic microorganisms that has developed resistance to the antibiotics in the current regimen [3,7]. However, additional mutations may compensate for this fitness cost and aids the survival of these bacteria. Hence, the search for a new and potent antimicrobial agents is gaining interest. When the era of synthetic drugs began, it opened up thousand doors for the development of various synthetic molecules with a potential action. The compounds with the backbone of benzophenones have been reported to possess various biological activities such as anticancer [8] antimicrobial [9] antioxidant [10]. 1,3,4-Oxadiazole ring is associated with many types of biological properties such as anti-inflammatory [11-13], hypoglycemic [14], antifungal and antibacterial [15-19] activities. 1,3,4-Oxadiazoles and its derivatives have a broad range of biological and pharmacological properties and are widely used as starting materials for the synthesis of a broad range of heterocyclic compounds and substrates for the drug synthesis. Some of its derivatives show a wide range of biological and pharmacological activity, such as anticancer $[8,20]$ antiviral activities
[21]. Prompted by these, the present paper emphasizes on the synthesis, characterization and antimicrobial evaluation of 2,5-di(4 aryloylaryloxy methyl)- 1,3,4-oxadiazoles derivatives. All the synthesized compounds were characterized on the basis of their physical properties IR, ${ }^{1} \mathrm{H}$ and ${ }^{13} \mathrm{C}$ NMR spectral data and elemental analysis. The physical data of titled compounds are summarized and present in the result and discussion part.

\section{Materials and Methods}

\section{Experimental section}

All solvents and reagents were purchased from Sigma Aldrich Chemicals Pvt Ltd. TLC was performed on aluminum-backed silica plates and visualized by UV-light. Melting points (M.P) were determined on an electrically heated VMP-III melting point apparatus. The elemental analysis of the compounds was performed on a Perkin Elmer 2400 elemental analyzer. The results of elemental analyses were within $\pm 0.4 \%$ of the theoretical values. The FT-IR spectra were recorded using $\mathrm{KBr}$ discs and Nujol on FT-IR Jasco 4100 infrared spectrophotometer. ${ }^{1} \mathrm{H}$ NMR spectra were recorded on a Bruker 400 $\mathrm{MHz} \mathrm{NMR}$ spectrometer in $\mathrm{CDCl}_{3}$ or DMSO and the chemical shifts were recorded in parts per million downfi ld from tetramethylsilane. Mass spectra were recorded on LC-MS (API-4000) mass spectrometer. MTT was purchased from Sigma Aldrich, USA and CD31 antibodies were procured from Santa Cruz, USA.

\section{Synthesis}

General procedure for substituted arylbenzoates (3a-e): 2-Chloro-6-fluoro phenol $(1,0.2054 \mathrm{~mol})$ was dissolved in DCM, triethylamine (TEA, $0.4519 \mathrm{~mol}$ ) was added and the reaction mixture was cooled to $0^{\circ} \mathrm{C}$. A solution of benzoyl chloride derivatives (2ae, $0.2157 \mathrm{~mol}$ ) in DCM was added slowly to the above mixture and

*Corresponding author: Shaukath Ara Khanum, Department of chemistry, Yuvaraja's College, University of Mysore, Mysore, Karnataka, India, Tel: +919901888755; E-mail: shaukathara@yahoo.co.in

Received March 03, 2017; Accepted April 06, 2017; Published April 10, 2017

Citation: Eissa Mohammed YH, Gurupadaswamy HD, Khanum SA (2017) Biological Evaluation of 2, 5-Di (4 Aryloylaryloxy Methyl) - 1, 3, 4-Oxadiazoles Derivatives as Antimicrobial Agents. Med Chem (Los Angeles) 7: 837-843. doi: 10.4172/21610444.1000438

Copyright: @ 2017 Eissa Mohammed YH, et al. This is an open-access article distributed under the terms of the Creative Commons Attribution License, which permits unrestricted use, distribution, and reproduction in any medium, provided the original author and source are credited. 
stirred for $3 \mathrm{~h}$. Then the reaction mass was diluted with DCM $(200 \mathrm{~mL})$, washed with $10 \%$ sodium hydroxide solution $(3 \times 30 \mathrm{~mL})$, water $(3 \times 30$ $\mathrm{mL})$, brine $(2 \times 60 \mathrm{~mL})$, and again with water $(3 \times 30 \mathrm{~mL})$. The organic layer was dried over sodium sulfate and the solvent was evaporated to achieve compounds 3a-e [8].

Synthesis of 2-chloro-6-fluorophenyl-4-fluorobenzoate (3a): 2-Chloro-6-fluoro phenol (1, $30 \mathrm{~g}, 0.2054 \mathrm{~mol})$ was dissolved in DCM, triethylamine (TEA, $45.73 \mathrm{~g}, 0.4519 \mathrm{~mol}$ ) was added and the reaction mixture was cooled to $0^{\circ} \mathrm{C}$. A solution of 4 -fluorobenzoyl chloride $(\mathbf{2 a}$, $33.9 \mathrm{~g}, 0.2157 \mathrm{~mol}$ ) in DCM was added slowly to the above mixture and internal temperature was maintained to $0-10^{\circ} \mathrm{C}$. Finally the reaction mixture was stirred at ambient temperature for $3 \mathrm{~h}$. Then the reaction mass was diluted with DCM $(200 \mathrm{~mL})$, washed with $10 \%$ sodium hydroxide solution $(3 \times 30 \mathrm{~mL})$, water $(3 \times 30 \mathrm{~mL})$, brine $(2 \times 60 \mathrm{~mL})$, and again with water $(3 \times 30 \mathrm{~mL})$. The organic layer was dried over sodium sulfate and the solvent was evaporated to achieve compound 3a as white solid. Yield: $94 \%$; m.p.: $52.6-54.1^{\circ} \mathrm{C}$; IR $(\mathrm{KBr}) \operatorname{nmax}\left(\mathrm{cm}^{-1}\right)$ : 1738 (ester, $\mathrm{C}=\mathrm{O}) ;{ }^{1} \mathrm{H}$ NMR (400 MHz) (DMSO-d6) d (ppm): 7.42-7.53 (m, 4H, Ar-H), 8.25-8.28 (m, 3H, Are-H); MS (EI): m/z (75\%) M+1 268.5; Anal. Calcd. for $\mathrm{C}_{13} \mathrm{H}_{7} \mathrm{ClF}_{2} \mathrm{O}_{2}$ (268.5): C, 58.12; $\mathrm{H}, 2.63 ; \mathrm{Cl}, 13.20$; F, 14.14. Found: C, 58.22; H, 2.43; Cl, 13.30; F, 14.29\%. Compounds $3 \mathrm{~b}$-e were synthesized analogously starting with $2 \mathrm{~b}$-e respectively by same method [8].

General procedure for (4-hydroxyaryl)aryl methanones (4a-e): Compound 3a-e $(0.1903 \mathrm{~mol})$ and aluminum chloride $(0.5388 \mathrm{~mol})$ were blended and the mixture was heated to $150^{\circ} \mathrm{C}$ and this temperature was maintained for $1 \mathrm{~h}$. Then the reaction mixture was cooled to $0^{\circ} \mathrm{C}$ and quenched with $6 \mathrm{~N}$ hydrochloric acid $(200 \mathrm{~mL})$ and extracted with $\mathrm{DCM}(3 \times 100 \mathrm{~mL})$. The organic layer was washed with water $(3 \times 40$ $\mathrm{mL})$, brine $(3 \times 30 \mathrm{~mL})$ and again with water $(3 \times 40 \mathrm{~mL})$. The organic layer was dried over anhydrous sodium sulfate and the solvent was evaporated to afford compounds 4a-e.

Synthesis of (3-chloro-5-fluoro-4-hydroxyphenyl)4- fluorophenyl methanone (4a): Compound 3a (51 g, $0.1903 \mathrm{~mol}$ ) and aluminum chloride $(71.05 \mathrm{~g}, 0.5388 \mathrm{~mol})$ were blended and the mixture was heated to $150^{\circ} \mathrm{C}$ and this temperature was maintained for $1 \mathrm{~h}$. Then the reaction mixture was cooled to $0^{\circ} \mathrm{C}$ and quenched with $6 \mathrm{~N}$ hydrochloric acid $(200 \mathrm{~mL})$ and extracted with DCM $(3 \times 100 \mathrm{~mL})$. The combined organic layer was washed with water $(3 \times 40 \mathrm{~mL})$, brine $(3 \times$ $30 \mathrm{~mL})$ and again with water $(3 \times 40 \mathrm{~mL})$. The organic layer was dried over anhydrous sodium sulfate and the solvent was evaporated to afford compound 4a as pale yellow solid. Yield: $61 \%$; m.p.: $146.3-147.7^{\circ} \mathrm{C}$; IR $(\mathrm{KBr}) \mathrm{nmax}\left(\mathrm{cm}^{-1}\right): 1671(\mathrm{C}=\mathrm{O}), 3545-3635(\mathrm{OH}) ;{ }^{1} \mathrm{H}$ NMR $(400 \mathrm{MHz})$ (DMSO-d6) d (ppm): 7.36-7.82 (m, 6H, Ar-H), 11.64 (bs, 1H, OH). MS (EI): $\mathrm{m} / \mathrm{z}(83 \%): \mathrm{M}+268.5$; Anal. Calcd. for $\mathrm{C}_{13} \mathrm{H}_{7} \mathrm{ClF}_{2} \mathrm{O}_{2}$ (268.5): C, 58.12; H, 2.63; Cl, 13.20; F, 14.14. Found: C, 58.21; H, 2.52; Cl, 13.20; F, $14.25 \%$. Compounds $4 \mathbf{b}-\mathbf{e}$ were synthesized analogously starting with $\mathbf{3 b}$-e respectively by same method [8].

General procedure for ethyl 4-aryloylaryloxyacetates (5a-e): To a solution of compounds 4a-e $(0.1156 \mathrm{~mol})$ in dry DMF $(175 \mathrm{~mL})$, potassium carbonate $(0.3468 \mathrm{~mol})$ and ethyl bromoacetate $(0.1273$ mol) were added and the reaction mass was heated to $60^{\circ} \mathrm{C}$ for $3 \mathrm{~h}$. The reaction mass was diluted with ethyl acetate $(200 \mathrm{~mL})$, potassium carbonate was filtered off and the bed was washed with ethyl acetate $(100 \mathrm{~mL})$. The organic layer was washed with water $(3 \times 30 \mathrm{~mL})$, brine $(2 \times 40 \mathrm{~mL})$, dried over sodium sulfate and concentrated to yield compounds 5a-e.

Synthesis of ethyl [2-(4-fluorobenzoyl)-2-chloro-6-fluorophenoxy] acetate (5a): To a solution of compound $4 \mathrm{a}(31 \mathrm{~g}, 0.1156 \mathrm{~mol})$ in dry
DMF $(175 \mathrm{~mL})$, potassium carbonate $(47.83 \mathrm{~g}, 0.3468 \mathrm{~mol})$ and ethyl bromoacetate $(21.11 \mathrm{~g}, 0.1273 \mathrm{~mol})$ were added and the reaction mass was heated to $60^{\circ} \mathrm{C}$ and maintained for $3 \mathrm{~h}$. The reaction mass was diluted with ethyl acetate $(200 \mathrm{~mL})$, potassium carbonate was filtered off and the bed was washed with ethyl acetate $(100 \mathrm{~mL})$. The organic layer was washed with water $(3 \times 30 \mathrm{~mL})$, brine $(2 \times 40 \mathrm{~mL})$, dried over sodium sulfate and concentrated to yield compound $\mathbf{5 a}$ as brown pasty mass. Yield: 97\%; IR $(\mathrm{KBr}) \mathrm{nmax}\left(\mathrm{cm}^{-1}\right): 1660(\mathrm{C}=\mathrm{O}), 1730$ (ester, $\mathrm{C}=\mathrm{O}) ;{ }^{1} \mathrm{H}$ NMR (400 MHz) (DMSO-d6) d (ppm): 1.16-1.22 (t, $3 \mathrm{H}$, CH3), 4.14-4.21 (q, 2H, CH2), 5.02 (s, 2H, OCH2), 7.64-7.8 (m, 6H, Ar-H). MS (EI): m/z (59\%): $\mathrm{M}+1$ 354.5; Anal. Calcd. for $\mathrm{C}_{17} \mathrm{H}_{13} \mathrm{ClF}_{2} \mathrm{O}_{4}$ (354.5): C, 57.56; H, 3.69; Cl, 9.99; F, 10.71. Found: C, 57.41; H, 3.52; $\mathrm{Cl}, 9.79 ; \mathrm{F}, 10.88 \%$. Compounds 5b-e were synthesized analogously starting with $\mathbf{4 b}$-e respectively by same method [8].

General procedure for 4-aryloylaryloxyethanoic acids (6a-e): A mixture of compounds 5a-e $(0.0532 \mathrm{~mol}), 10 \%$ aqueous sodium hydroxide solution $(100 \mathrm{~mL})$ and THF $(100 \mathrm{~mL})$ was stirred at room temperature for $1 \mathrm{~h}$. The reaction mass was acidifi $\mathrm{d}$ with $6 \mathrm{~N}$ hydrochloric acid $(150 \mathrm{~mL})$ and the aqueous layer was extracted with ethyl acetate $(3 \times 100 \mathrm{~mL})$. The organic layer was washed with brine ( 3 $\times 60 \mathrm{~mL}$ ), dried over anhydrous sodium sulfate and concentrated to achieve compounds 6a-e.

Synthesis of [4-(4-fluorobenzoyl)-2-chloro-6-fluorophenoxy] ethanoic acid (6a): A mixture of compound 5a (18 g, $0.0532 \mathrm{~mol}), 10 \%$ aqueous sodium hydroxide solution $(100 \mathrm{~mL})$ and THF $(100 \mathrm{~mL})$ was stirred at room temperature for $1 \mathrm{~h}$. The reaction mass was acidifi $\mathrm{d}$ with $6 \mathrm{~N}$ hydrochloric acid $(150 \mathrm{~mL})$ and the aqueous layer was extracted with ethyl acetate $(3 \times 100 \mathrm{~mL})$. The organic layer was washed with brine $(3 \times 60 \mathrm{~mL})$, dried over anhydrous sodium sulfate and concentrated to achieve compound $\mathbf{6 a}$ as white solid. Yield: $92 \%$; m.p.: $127.3-128.6^{\circ} \mathrm{C}$; IR $(\mathrm{KBr}) \operatorname{nmax}\left(\mathrm{cm}^{-1}\right): 1660(\mathrm{C}=\mathrm{O}), 1738($ acid $\mathrm{C}=\mathrm{O}), 3470-3575$ (acid $\mathrm{OH}) ;{ }^{1} \mathrm{H}$ NMR (400 MHz) (DMSO-d6) d (ppm): 4.9 (s, 2H, OCH2), 7.3-7.87 (m, 6H, AreH), 13.1 (s, 1H, COOH). MS (EI): m/z (55\%): Mp 326.5; Anal. Calcd. for $\mathrm{C}_{15} \mathrm{H}_{9} \mathrm{ClF}_{2} \mathrm{O}_{4}$ (326.5): C, $55.15 ; \mathrm{H}, 2.78$; $\mathrm{Cl}, 10.85$; F, 11.63. Found: C, 55.25; H, 2.61; Cl, 10.72; F, 11.49\%. Compounds $\mathbf{6 b}$-e were synthesized analogously starting with $\mathbf{5 b}$-e respectively by same method [8].

General procedure for 4-aryloylaryloxyacethydrazides (7a-e): Hydrazine hydrate $(0.3372 \mathrm{~mol})$ was added to a solution of compounds 6a-e $(0.0562 \mathrm{~mol})$ in ethanol $(100 \mathrm{~mL})$ at $0^{\circ} \mathrm{C}$ and stirred the reaction mixture at the same temperature for $1 \mathrm{~h}$. A white solid was separated out, which was quenched with water $(100 \mathrm{~mL})$, filtered and washed with water $(50 \mathrm{~mL})$. Finally, solid was dried under vacuum to obtain compounds $7 \mathbf{a}-\mathbf{e}$.

Synthesis of 2-[4-(4-fluorobenzoyl)-2-chloro-6-fluorophenoxy] acethydrazide (7a): Hydrazine hydrate ( $16.90 \mathrm{~g}, 0.3372 \mathrm{~mol}$ ) was added to a solution of compound $\mathbf{6 a}(19 \mathrm{~g}, 0.0562 \mathrm{~mol})$ in ethanol $(100 \mathrm{~mL})$ at $0^{\circ} \mathrm{C}$ and stirred the reaction mixture at the same temperature for $1 \mathrm{~h}$. A white solid was separated out, which was quenched with water (100 $\mathrm{mL})$, filtered and washed with water $(50 \mathrm{~mL})$. Finally, solid was dried under vacuum to obtain compound $7 \mathbf{a}$ as white needle.

Yield: 79\%; m.p.: $107.5-109.1^{\circ} \mathrm{C}$; IR (KBr) $\operatorname{nmax}\left(\mathrm{cm}^{-1}\right): 1610$ $(\mathrm{C}=\mathrm{O}), 1645$ (amide, $\mathrm{C}=\mathrm{O}), 3100-3205$ (NH-NH2); ${ }^{1} \mathrm{H}$ NMR $(400$ $\mathrm{MHz}$ (DMSO-d6) d (ppm): 4.35 (bs, 2H, NH2), 4.69 (s, 2H, OCH2), 7.2-7.86 (m, 6H, Ar-H), 9.32 (bs, $1 \mathrm{H}, \mathrm{CONH}) . \mathrm{MS}$ (EI): $\mathrm{m} / \mathrm{z}(42 \%)$ : $\mathrm{M}+340.5$; Anal Calcd. for $\mathrm{C}_{15} \mathrm{H}_{11} \mathrm{ClF}_{2} \mathrm{~N}_{2} \mathrm{O}_{3}$ (340.5): C, 52.88; $\mathrm{H}, 3.25$; $\mathrm{Cl}, 10.41 ; \mathrm{F}, 11.15 ; \mathrm{N}, 8.22$. Found: C, 52.75; H, 3.38; Cl, 10.29; F, 11.24 $\mathrm{N}, 8.11 \%$. Compounds $7 \mathbf{b}-\mathbf{e}$ were synthesized analogously starting with 6b-e respectively by same method [8]. 
General procedure for N,N-di(2-(4-aryloylaryloxy)acetyl) hydrazines $(\mathbf{8} \mathbf{a}-\mathbf{j})$ : To a solution of compounds $\mathbf{6 a}-\mathbf{e}(0.0032 \mathrm{~mol})$ in DCM $(20 \mathrm{~mL}), 2,6$-dimethylpyridine $(0.0107 \mathrm{~mol})$ and TBTU $(0.00323$ mol) were added at room temperature. Finally, compounds 7 a-e $(0.00294 \mathrm{~mol})$ were added to the reaction mixture and stirred at room temperature for $12 \mathrm{~h}$. The reaction mixture was quenched with $10 \%$ sodium bicarbonate solution $(20 \mathrm{~mL})$ and stirred for $30 \mathrm{~min}$. The solid precipitate was filtered, washed with water $(20 \mathrm{~mL})$ and dried to yield compounds 8a-j.

Synthesis of $\mathrm{N}, \mathrm{N}$-di[di(2-chloro-6-fluoro-4-(4-fluoro-benzoyl) phenoxy)]acetyl hydrazide (8a): To a solution of compound 6a (1.05 g, $0.0032 \mathrm{~mol})$ in DCM $(20 \mathrm{~mL}), 2,6$-dimethylpyridine $(1 \mathrm{~g}, 0.0107$ $\mathrm{mol})$ and TBTU $(1.04 \mathrm{~g}, 0.00323 \mathrm{~mol})$ were added at room temperature. Finally, compound $7 \mathbf{a}(1 \mathrm{~g}, 0.00294 \mathrm{~mol})$ was added to the reaction mixture and stirred at room temperature for $12 \mathrm{~h}$. The reaction mixture was quenched with $10 \%$ sodium bicarbonate solution $(20 \mathrm{~mL})$ and stirred for $30 \mathrm{~min}$. The solid precipitate was filtered, washed with water $(20 \mathrm{~mL})$ and dried to yield compound $\mathbf{8 a}$ as white solid. Yield: 81\%; m.p.: $194.8-196.2^{\circ} \mathrm{C}$; IR (KBr) nmax $\left(\mathrm{cm}^{-1}\right)$ : $1690(\mathrm{C}=\mathrm{O}), 1610$ (amide, $\mathrm{C}=\mathrm{O})$, 3700-3500 (NH-NH); ${ }^{1} \mathrm{H}$ NMR (400 MHz) (DMSO-d6) d (ppm): 4.90 (s, 4H, 2CH2), 7.1-7.87 (m, 12H, Ar-H), 10.36 (bs, $2 \mathrm{H}$, 2NH). MS (EI): m/z (61\%): $\mathrm{M}+1$ 649; Anal. Calcd. For $\mathrm{C}_{30} \mathrm{H}_{18} \mathrm{Cl}_{2} \mathrm{~F}_{4} \mathrm{~N}_{2} \mathrm{O}_{6}$ (649): C, 55.49; H, 2.79; N, 4.31. Found: C, 55.37; H, 2.88; N, 4.43\%. Similarly compounds $\mathbf{8 b}$-j were synthesized starting from compounds 6b-e and 7a-e by same method [8].

General procedure for 2,5-di(4-aryloylaryloxymethyl)-1,3,4oxadiazoles (9a-j): To a solution of compounds $8 \mathrm{a}-\mathrm{j}(0.0023 \mathrm{~mol})$ in DCM $(20 \mathrm{~mL})$, pyridine $(0.0069 \mathrm{~mol})$ and triflic anhydride $(0.0051$ mol) were added at $0^{\circ} \mathrm{C}$ and the reaction mixture was stirred at $0^{\circ} \mathrm{C}$ for $3 \mathrm{~h}$. The reaction mass was diluted with DCM $(20 \mathrm{~mL})$, the organic layer was washed with $10 \%$ sodium bicarbonate $(3 \times 10 \mathrm{~mL})$, water $(3 \times$ $10 \mathrm{~mL})$ and brine $(3 \times 10 \mathrm{~mL})$. Finally, the organic layer was dried over sodium sulfate and concentrated to yield compounds $\mathbf{9 a - j}$.

Synthesis of 2,5-di[2-fluoro-4-(4-fluoro)benzoyl-6chlorophenoxymethyl]1,3,4-oxadiazole (9a): To a solution of compound 8a (1.5 g, $0.0023 \mathrm{~mol})$ in DCM $(20 \mathrm{~mL})$, pyridine $(0.56$ $\mathrm{g}, 0.0069 \mathrm{~mol})$ and triflic anhydride $(1.44 \mathrm{~g}, 0.0051 \mathrm{~mol})$ were added at $0^{\circ} \mathrm{C}$ and the reaction mixture was stirred at $0^{\circ} \mathrm{C}$ for $3 \mathrm{~h}$. After the completion of the reaction monitored by TLC, the reaction mass was diluted with DCM $(20 \mathrm{~mL})$, the organic layer was washed with $10 \%$ sodium bicarbonate $(3 \times 10 \mathrm{~mL})$, water $(3 \times 10 \mathrm{~mL})$ and brine $(3 \times$ $10 \mathrm{~mL}$ ). Finally, the organic layer was dried over sodium sulfate and concentrated to yield a brown gummy mass. The crude product was purifi $\mathrm{d}$ by column chromatography using silica gel as stationary phase and hexane: ethyl acetate as mobile phase to achieve compound $9 \mathbf{a}$ as white solid. Yield; $73 \%$; m.p.: $129.5-130.2^{\circ} \mathrm{C}$; IR (Nujol) $\mathrm{nmax}\left(\mathrm{cm}^{-1}\right)$ : 1153 (C-O-C linkage), $1658(\mathrm{C}=\mathrm{O}), 1683 \mathrm{~cm}^{-1}(\mathrm{C}=\mathrm{N}) ;{ }^{1} \mathrm{H}$ NMR $(400$ $\mathrm{MHz}$ (DMSO-d6) d (ppm): 5.6 (s, 4H, 2CH2), 7.05-7.81 (m, 12H, ArH). MS (EI): m/z (70\%): $\mathrm{M}+1$ 631; Anal. Calcd. For $\mathrm{C}_{30} \mathrm{H}_{16} \mathrm{Cl}_{2} \mathrm{~F}_{4} \mathrm{~N}_{2} \mathrm{O}_{5}$ (631): C, 57.07; H, 2.55; N, 4.44. Found: C, 57.17; H, 2.47; N, 4.36\%. Similarly compounds $\mathbf{9 b}$-j were synthesized starting from compounds $\mathbf{8 b}$-j by same method [8].

\section{Biology}

Materials and methods for the antimicrobial activity: Streptomycin was used as positive control against bacteria. Ketoconazole (Himedia, Mumbai) was used as positive control against fungi.

Tested microbes: The following gram positive bacteria were used for the experiments; staphylococcus aureus (MTCC 7443), B. cereus,
Staphylococcus aureus (MRSA) (MTCC 84), B. subtilis, Enterobacter aerogenes (MTCC 111). The gram negative bacteria included Escherichia coli, P. aeruginosa, Salmonella typhimurium (MTCC 2488), Klebsiella pneumoniae (MTCC 109), and Salmonella paratyphi-B (MTCC 733). In addition, fungi $A$. niger, Candida albicans (MTCC 227), Botyritis cinerea (MTCC 2880), F. solani, A. flavus, Candida krusei (MTCC 231), Malassesia pachydermatis, F. moniliforme, C. gloeosporioides and C. parapsilosis were also used for the experiments. All cultures were obtained from the Department of Microbiology, Manasagangotri, Mysuru.

Preparation of inoculums: Bacterial inoculums were prepared by growing cells in Mueller Hinton Broth (MHA) (Himedia) for $24 \mathrm{~h}$ at $37^{\circ} \mathrm{C}$. These cell suspensions were diluted with sterile MHB to provide initial cell counts of about $104 \mathrm{CFU} / \mathrm{mL}$. The filamentous fungi were grown on Sabouraud Dextrose Agar (SDA) slants at $28^{\circ} \mathrm{C}$ for 10 days and the spores were collected using sterile double distilled water and homogenized.

Disc diffusion assay: Antibacterial activity was carried out using a disc diffusion method (Murray) [21]. Petri plates were prepared with $20 \mathrm{~mL}$ of sterile Mueller Hinton Agar (MHA) (Himedia, Mumbai). The test cultures were swabbed on the top of the solidifi $\mathrm{d}$ media and were allowed to dry for 10 mins. The tests were conducted at $1000 \mu \mathrm{g} / \mathrm{disc}$. The loaded discs were placed on the surface of the medium and left for $30 \mathrm{~min}$ at room temperature for compound diffusion. Negative control was prepared using respective solvent. Streptomycin $(10 \mu \mathrm{g} / \mathrm{disc})$ was used as positive control. The plates were incubated for $24 \mathrm{~h}$ at $37^{\circ} \mathrm{C}$ for bacteria and $48 \mathrm{~h}$ at $27^{\circ} \mathrm{C}$ for fungi. Zone of inhibition was recorded in millimeters and the experiment was repeated twice.

Minimum inhibitory concentration (MIC): Minimum inhibitory concentration studies of synthesized compounds were performed according to the standard reference method for bacteria (Duraipandiyan and Ignacimuthu) [22] and filamentous fungi (Clinical and Laboratory Standards Institute). Required concentrations $(1000 \mu \mathrm{g} / \mathrm{mL}, 500 \mu \mathrm{g} / \mathrm{mL}$, $250 \mu \mathrm{g} / \mathrm{mL}, 125 \mu \mathrm{g} / \mathrm{mL}, 62.5 \mu \mathrm{g} / \mathrm{mL}, 31.25 \mu \mathrm{g} / \mathrm{mL}$ and $15.62 \mu \mathrm{g} / \mathrm{mL}$ ) of the compound were dissolved in DMSO (2\%), and diluted to give serial two-fold dilutions that were added to each medium in 96 well plates. An inoculum of $100 \mathrm{~mL}$ from each well was inoculated. The antifungal agents ketoconazole for fungi and streptomycin for bacteria were included in the assays as positive controls. For fungi, the plates were incubated for $48-72 \mathrm{~h}$ at $28^{\circ} \mathrm{C}$ and for bacteria the plates were incubated for $24 \mathrm{~h}$ at $37^{\circ} \mathrm{C}$. The MIC for fungi was defi ed as the lowest extract concentration, showing no visible fungal growth after incubation time. $5 \mathrm{Ml}$ of tested broth was placed on the sterile MHA plates for bacteria and incubated at respective temperatures. The MIC for bacteria was determined as the lowest concentration of the compound inhibiting the visual growth of the test cultures on the agar plate.

\section{Results and Discussion}

\section{Chemistry}

The synthesis of the hitherto unreported title compounds is as outlined in Scheme 1. (4 Hydroxyaryl)aryl methanones commonly known as hydroxybenzophenones 4a-e were achieved in excellent yield using benzoylation of compound $\mathbf{1}$ with benzoyl chloride derivatives 2a-e followed by Fries rearrangement of substituted arylbenzoates 3a-e. Compounds 4a-e on reaction with ethyl bromoacetate afforded ethyl 4-aryloylaryloxyacetates 5a-e which on treatment with sodium hydroxide in presence of THF gave 4- aryloylaryloxyethanoic acids 6a-e. Further, compounds 5a-e on treatment with hydrazine hydrate in the presence of ethanol yield 4-aryloylaryloxyacethydrazides 


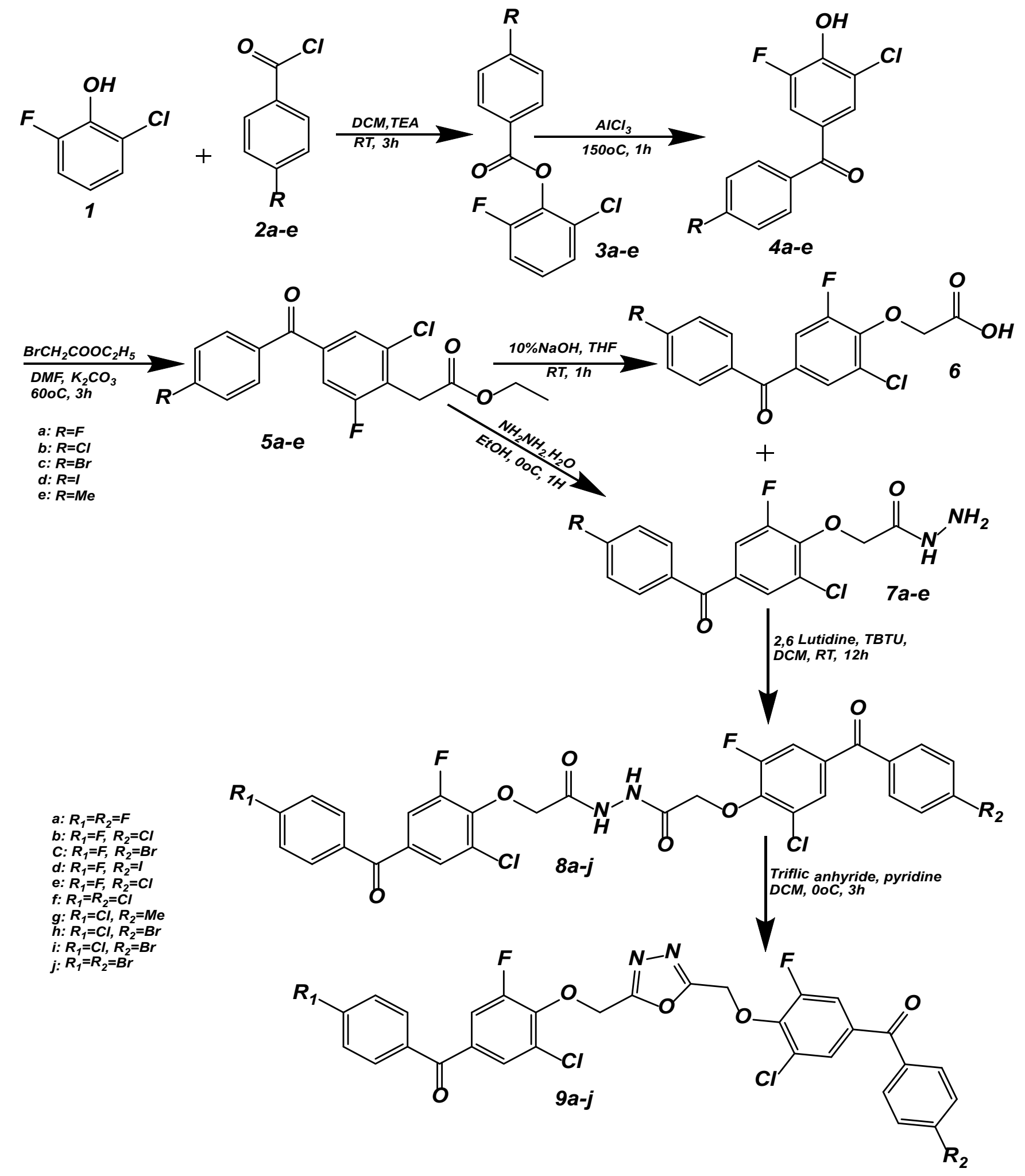

Scheme 1: Synthesis of the hitherto unreported title compounds.

7a-e. Condensation of 6a-e with $7 \mathbf{a}-\mathbf{e}$ in the presence of 2,6 lutidine, O-(benzotriazol-1-yl)-N,N,N0,N0-tetramethyluronium tetrafluoroborate (TBTU) and dichloromethane (DCM) afforded N,N- di(2-(4-aryloylaryloxy) acetyl)hydrazines 8a-j. Finally, title compounds $\mathbf{9 a - j}$ were achieved by intramolecular cyclization of $\mathbf{8 a - j}$ in the presence of triflic nhydride, pyridine and DCM. 


\section{In vitro anti-microbial activity}

Anti-bacterial activity assay: The anti-bacterial screenings of the synthesized compounds were undertaken using disc diffusion method. The screening results of the tested compounds against the gram positive bacteria (Staphylococcus aureus (MTCC 7443), B. cereus, Staphylococcus aureus (MRSA) (MTCC 84), B. subtilis, M. luteus, Enterobacter aerogenes (MTCC 111), gram negative bacteria (Escherichia coli, P. aeruginosa, $P$. vulgaris, Salmonella typhimurium (MTCC 2488), Klebsiella pneumoniae (MTCC 109), Salmonella paratyphi-B (MTCC 733), in addition to the pathogenic fungi A. niger, Candida albicans (MTCC 227), Botyritis cinereal (MTCC 2880), F. solani, A. flavus, Candida krusei (MTCC 231), Malassesia pachydermatis, F. moniliforme C. gloeosporioides C. parapsilosis are summarized in Figure 1 and Table 1.

In antibacterial activity the obtained data revealed that most of the compounds showed moderate to excellent activities against the tested microorganisms. Among all the synthesized substituted 2,5$\operatorname{di}(4$ aryloylaryloxy methyl)- 1,3,4-oxadiazoles compounds $\mathbf{9 a - j}$, compounds 9 a with fluoro group exhibited highest activity compared with the standard drug Streptomycin. Compounds $9 \mathrm{c}$ with fluoro and bromo groups has shown second highest activity. Further, compounds 9b with fluoro and chloro groups, 9d with fluoro and iodo groups, 9f with chloro group and $\mathbf{9 j}$ with bromo group also exhibited moderate activity.

Anti-fungi activity assay: The anti-bacterial screenings of the synthesized compounds were undertaken using disc diffusion method. The screening results of the tested compounds against the pathogenic fungi A. niger, Candida albicans (MTCC 227), Botyritis cinereal (MTCC 2880), F. solani, A. flavus, Candida krusei (MTCC 231), Malassesia pachydermatis, F. moniliforme, C. gloeosporioides, C. parapsilosis are summarized in Figure 2 and Table 2.

In anti-fungi activity assay the obtained data shown that most of the compounds showed moderate to excellent activities against the tested microorganisms. Among all the synthesized substituted 2,5-di(4 aryloylaryloxy methyl)- 1,3,4-oxadiazoles compounds $\mathbf{9 a - j}$, compounds 9a with fluoro group exhibited highest activity compared with the standard drug Ketoconazole. Compounds $\mathbf{9 b}$ with fl oro and chloro groups, 9c with fluoro and bromo groups, 9d with fl oro and iodo groups and $9 \mathrm{~h}$ with chloro and iodo groups has shown good activity. Further, compounds, $\mathbf{9 i}$ with chloro and bromo groups and $\mathbf{9 j}$ with bromo group also showed moderate activity.

\section{Conclusion}

From the results of the present study, it is concluded that, a series of novel biologically active substituted 2,5-di(4 aryloylaryloxymethyl)1,3,4-oxadiazoles 9a-j were synthesized and screened for antimicrobial activity and were compared with standard drugs-Streptomycin and Ketoconazole respectively. The antibacterial activity result shows that compound 9a with fluoro group exhibited highest activity. Compounds 9c with fluoro and bromo groups has shown second highest activity. Further, compounds $\mathbf{9 b}$ with fluoro and chloro groups, $\mathbf{9 d}$ with $\mathrm{fl}$ oro and iodo groups, $\mathbf{9 f}$ with chloro group and $\mathbf{9 j}$ with bromo group also exhibited moderate activity. Further, The Antifungal activity of the compounds 9a-j result shows that compound 9a with fl oro group exhibited highest activity. Compounds $9 \mathrm{~b}$ with fluoro and chloro groups, 9c with fluoro and bromo groups, 9d with fluoro and iodo groups and $9 \mathrm{~h}$ with chloro and iodo groups has shown good activity.
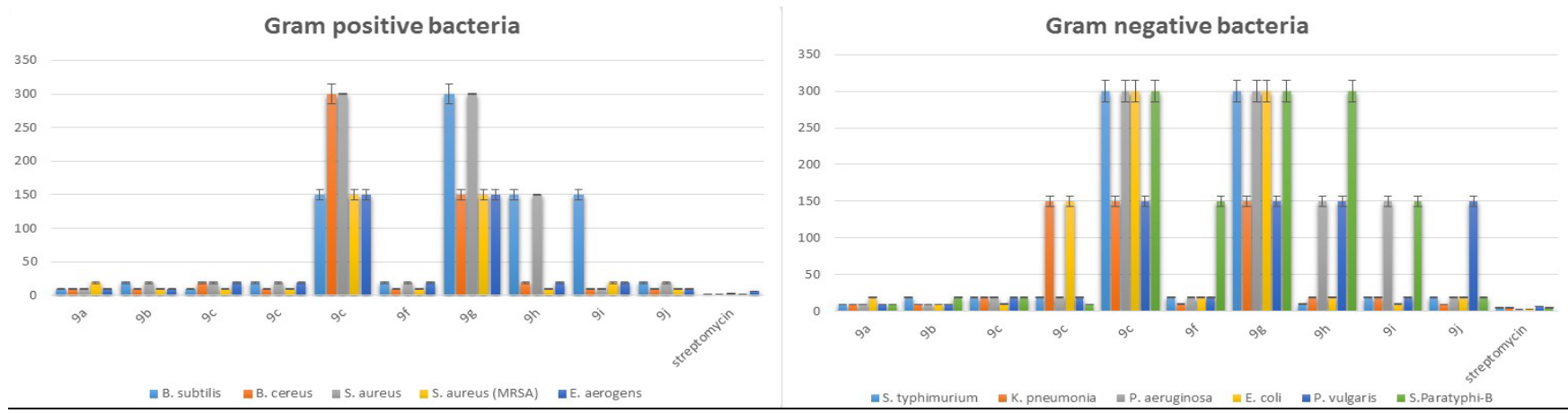

Figure 1: The inhibitory effects of compounds 9a-j on Gram positive and Gram negative bacteria.

\begin{tabular}{|c|c|c|c|c|c|c|c|c|c|c|}
\hline \multirow[t]{2}{*}{ Compounds } & \multicolumn{10}{|c|}{ Name of the microorganism MIC in $\mathrm{mg} / \mathrm{mL}$} \\
\hline & $\begin{array}{c}A . \\
\text { niger }\end{array}$ & $\begin{array}{c}\text { C. } \\
\text { albicans }\end{array}$ & $\begin{array}{c}A . \\
\text { flavus }\end{array}$ & $\begin{array}{c}\text { B. } \\
\text { cinerea }\end{array}$ & $\begin{array}{c}\text { C. } \\
\text { krusei }\end{array}$ & $\begin{array}{c}F . \\
\text { solani }\end{array}$ & C. parapsilosis & M. pachydermatis & F. moniliforme & C. gloeosporioides \\
\hline $9 a$ & 9.37 & 9.37 & 9. 37 & 18.75 & 9.37 & 9.37 & 9.37 & 18.75 & 9.37 & 9.37 \\
\hline $9 b$ & 9.37 & 18.75 & 9.37 & 9.37 & 18.75 & 9.37 & 9.37 & 18.75 & 18.75 & 9.37 \\
\hline $9 c$ & 9. 37 & 18.75 & 18.75 & 9. 37 & 18.75 & 9.37 & 9. 37 & 18.75 & 18.75 & 9. 37 \\
\hline $9 d$ & 9.37 & 150 & 18.75 & 9.37 & 9.37 & 18.75 & 18.75 & 9.37 & 150 & 9.37 \\
\hline $9 e$ & 300 & 300 & 150 & 150 & 300 & 150 & 300 & 300 & 300 & 150 \\
\hline $9 f$ & 18.75 & 150 & 9.37 & 18.75 & 9.37 & 9.37 & 9.37 & 18.75 & 150 & 18.75 \\
\hline $9 g$ & 150 & 150 & 300 & 300 & 150 & 300 & 300 & 300 & 150 & 300 \\
\hline $9 \mathrm{~h}$ & 9.73 & 9.73 & 18.75 & 9.73 & 18.75 & 18.75 & 150 & 9.73 & 150 & 18.75 \\
\hline $9 i$ & 18.75 & 9. 37 & 9.37 & 18.75 & 150 & 9. 37 & 18.75 & 18.75 & 9.37 & 150 \\
\hline 9j & 18.75 & 9.37 & 9.37 & 18.75 & 9.37 & 18.75 & 18.75 & 18.75 & 9.37 & 150 \\
\hline Ketoconazole & 2.4 & 4.6 & 1.2 & 4.7 & 2.33 & 2.34 & 4.68 & 4.68 & 2.34 & 2.34 \\
\hline
\end{tabular}

Table 1: Antibacterial activity of the compounds: 9a-j: MIC minimum inhibitory concentration MIC in $\mu \mathrm{gg} / \mathrm{mL}$. 


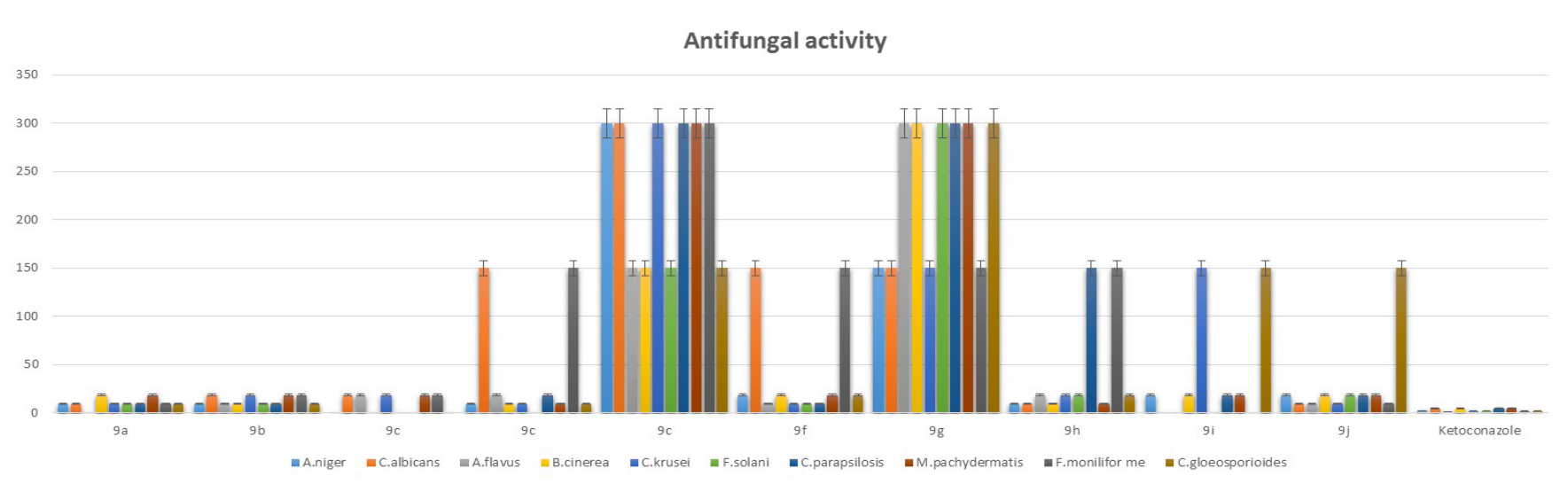

Figure 2: The inhibitory effects of compounds 9a-j on different fungal strain.

\begin{tabular}{|c|c|c|c|c|c|c|c|c|c|c|c|c|}
\hline \multirow[t]{3}{*}{ Compounds } & \multicolumn{12}{|c|}{ Name of microorganism (MIC in $\mathrm{mg} \mathrm{g} / \mathrm{mL}$ ) } \\
\hline & \multicolumn{6}{|c|}{ Gram positive bacteria } & \multicolumn{6}{|c|}{ Gram negative bacteria } \\
\hline & $\begin{array}{c}B . \\
\text { subtilis }\end{array}$ & $\begin{array}{c}B . \\
\text { cereus }\end{array}$ & $\begin{array}{c}\text { S. } \\
\text { aureus }\end{array}$ & $\begin{array}{l}\text { S. aureus } \\
\text { (MRSA) }\end{array}$ & M. luteus & E. aerogens & $\begin{array}{c}S . \\
\text { typhimurium }\end{array}$ & $\begin{array}{c}\text { K. } \\
\text { pneumonia }\end{array}$ & $\begin{array}{c}P . \\
\text { aeruginosa }\end{array}$ & E. coli & $\begin{array}{c}P . \\
\text { vulgaris }\end{array}$ & $\begin{array}{c}\text { S. } \\
\text { Paratyphi-B }\end{array}$ \\
\hline $9 a$ & 9.37 & 9.37 & 9.37 & 18.75 & 9.37 & 9.37 & 9.37 & 9.37 & 9.37 & 18.75 & 9.37 & 9.37 \\
\hline $9 b$ & 18.75 & 9.37 & 18.75 & 9.37 & 9.37 & 18.75 & 18.75 & 9.37 & 9.37 & 9.37 & 9.37 & 18.75 \\
\hline $9 c$ & 9.37 & 18.75 & 18.75 & 9.73 & 18.75 & 9.37 & 18.75 & 18.75 & 18.75 & 9.73 & 18.75 & 18.75 \\
\hline $9 d$ & 18.75 & 9.37 & 18.75 & 9.37 & 18.75 & 9.37 & 18.75 & 150 & 18.75 & 150 & 18.75 & 9.37 \\
\hline $9 e$ & 150 & 300 & 300 & 150 & 150 & 300 & 300 & 150 & 300 & 300 & 150 & 300 \\
\hline $9 f$ & 18.75 & 9.73 & 18.75 & 9.73 & 18.75 & 9.73 & 18.75 & 9.73 & 18.75 & 18.75 & 18.75 & 150 \\
\hline $9 g$ & 300 & 150 & 300 & 150 & 150 & 300 & 300 & 150 & 300 & 300 & 150 & 300 \\
\hline $9 \mathrm{~h}$ & 150 & 18.75 & 150 & 9.73 & 18.75 & 150 & 9.73 & 18.75 & 150 & 18.75 & 150 & 300 \\
\hline $9 i$ & 150 & 9.73 & 9.73 & 18.75 & 18.75 & 150 & 18.75 & 18.75 & 150 & 9.73 & 18.75 & 150 \\
\hline $9 \mathrm{j}$ & 18.75 & 9.37 & 18.75 & 9.37 & 9.37 & 150 & 18.75 & 9.37 & 18.75 & 18.75 & 150 & 18.75 \\
\hline Streptomycin & 2.34 & 1.17 & 2.35 & 2.38 & 6.34 & 4.5 & 4.68 & 4.68 & 2.34 & 2.34 & 6.68 & 4.68 \\
\hline
\end{tabular}

Table 2: Antifungal activity of the compounds: $9 a-j$ MIC in $\mu g g / M I$.

Further, compounds, $\mathbf{9 i}$ with chloro and bromo groups and $\mathbf{9 j}$ with bromo group also showed moderate activity.

\section{Acknowledgements}

Yasser Hussein Eissa Mohammed is thankful to the University of Hajja, Yemen, for providing financial assistance under the teacher's fellowship. Shaukath Ara Khanum expresses sincere gratitude to the Government of Karnataka, Vision Group on Science and Technology, Bangalore for the financial assistance and support (VGST/CISEE/2012-13/282 dated 16th March 2013) and UGC, New Delhi under the Major Research Project Scheme (F.39/737/2010 (SR)).

\section{References}

1. Unemo M, Fasth O, Fredlund H, Limnios A, Tapsall J (2009) Phenotypic and genetic characterization of the 2008 WHO Neisseria gonorrhoeae reference strain panel intended for global quality assurance and quality control of gonococcal antimicrobial resistance surveillance for public health purposes. $J$ Antimicrob Chemother 63: 1142-1151.

2. Berber I, Cokmus C, Atalan E (2003) Comparison of Staphylococcus spp. cellular and extracellular proteins by SDS-PAGE. Mikrobiologiia 72: 54-59.

3. Koca M, Servi S, Kirilmis C, Ahmedzade M, Kazaz C, et al. (2005) Synthesis and antimicrobial activity of (benzofuran-2-yl) (3-phenyl-3-methylcyclobutyl) ketoxime derivatives. Eur J Med Chem 40: 1351-1358.

4. Taun PT, Edmund LE, Joseph PS, Brian MW, Michael AS, et al. (2007) Structure activity relationships of 3-aminoquinazolinediones, a new class of bacterial type-2 topoisomerase (DNA gyrase and topo IV) inhibitors. Bioorg Med Chem Lett 17: 1312-1320.

5. Carpenter CF, Chambers HF (2004) Daptomycin: another novel agent for treating infections due to drug-resistant gram-positive pathogens. Clin Infect Dis 38: 994-1000.
6. Weigelt J, Itani K, Stevens D, Lau W, Dryden M, et al. (2005) Linzolid versus vancomycin in treatment of complicated skin and soft tissue infections. Antimicrob Agents Chemother 49: 2260-2266.

7. Yu D, Huiyuan G (2002) Synthesis and antibacterial activity of linezolid analogues. Bioorg Med Chem Lett 12: 857-859.

8. Gurupadaswamy HD, Girish V, Kavitha CV, Raghavan SC, Khanum SA (2013) Synthesis and evaluation of 2,5-di(4-aryloylaryloxymethyl)-1,3,4-oxadiazoles as anti-cancer agents. Eur J Med Chem 63: 536-543.

9. Sensi P, Gialdroni C (2003) Burger's Medicinal Chemistry and Drug Discovery 6th edn. John Wiley and Sons, New York, USA 5: 807.

10. Lipsitch M (2001) Trends in Microbiology. The Rise and Full of Antimicrobial Resistance, p: 438.

11. Mullican MD, Wilson MW, Connor DT, Kostlan CR, Schrier DJ, et al (1993) Design of 5-(3,5-di-tert-butyl-4-hydroxyphenyl)- 1,3,4 thiadiazoles, $-1,3,4$-oxadiazoles and -1,2,4-triazoles as orally-active, nonulcerogenic antiinflammatory agents. J Med Chem 36: 1090-1099

12. Boschelli DH, Connor DT, Bornemeier DA, Dyer RD, Kennedy JA, et al (1993) 1,3,4 Oxadiazole, 1,3,4-thiadiazole, and 1,2,4-triazole analogs of the fenamates: in vitro inhibition of cyclooxygenase and 5-lipoxygenase activities. J Med Chem 36: 1802-1810.

13. Raman K, Singh KH, Salzman SK, Parmar SS (1993) Substituted thiosemicarbazides and corresponding cyclized 1,3,4-oxadiazoles and their anti-inflammatory activit . J Pharm Sci 82: 167-169.

14. Sahin G, Palaska E, Kelicen P, Demirdamar R, Altinok G (2001) Synthesis of some new 1-acylthio-semicarbazides, 1,3,4-oxadiazoles, 1,3,4-thiadiazoles and 1,2,4-triazole-3-thiones and their anti-inflammatory activities. Arzneim Forsch Drug Res 51: 478-484. 
Citation: Eissa Mohammed YH, Gurupadaswamy HD, Khanum SA (2017) Biological Evaluation of 2, 5-Di (4 Aryloylaryloxy Methyl) - 1, 3, 4-Oxadiazoles Derivatives as Antimicrobial Agents. Med Chem (Los Angeles) 7: 837-843. doi: 10.4172/2161-0444.1000438

15. Husain MI, KumarA, Srivastava RC (1986) Synthesis of N-(2-naphthyloxyacetyl) thiosemicarbazides and 2-arylamino-5-(2 naphthyloxmethyl)-1,3,4-thiadiazoles/ oxadiazoles as oral hypoglycemic agents. Current Sci. 55: 644-646.

16. Giri S, Singh H, Yadav LDS (1976) Studies in oxadiazoles synthesis of some 2-mercapto-1,3,4-oxadiazoles and related compounds as potential fungicides. Agr Biol Chem 40: 17-21.

17. Singh H, Yadav LDS (1976) Synthesis of some 5-aryl-2-heteroarylamino1,3,4-oxadiazoles as potential fungicides. Agr Biol Chem 40: 759-764.

18. Misra HK (1983) Synthesis of some new substituted 1,3,4-oxadiazoles as potential insecticidal, antibacterial and anti-acetylcholine esterase agents. Arch Pharm 316: 487-493.
19. Khanum SA, Girish V, Suparshwa SS, Khanum NF (2009) Benzophenone-Nethyl piperidine ether analogues--synthesis and efficacy as anti-inflammatory agent. Bioorg Med Chem Lett 19: 1887-1891.

20. Lakshmi Ranganatha V, Prashanth T, Naveen P, Bushra Begum A, Mohammed A, et al. (2013) Evaluation of Antioxidant Activity of Diarylmethanone Integrated Thaiadiazine Analogues. Indo American Journal of Pharmaceutical Research 3: 4131

21. Duraipandiyan V, Ignacimuthu S (2009) Antibacterial and antifungal activity of Flindersine isolated from the traditional medicinal plant Toddalia asiatica (L.) Lam. J Ethnopharmacol 123: 494-498.

22. Burits M, Bucar F (2000) Antioxidant activity of Nigella sativa essential oil. Phytother Res 14: 323-328. 